\title{
Can "Letting in Sunlight" Lead to Accidental Sunburn? The Unintended Consequences of Campaign Finance Reform on the Financing of U.S. Presidential Candidates
}

\author{
Karen Sebold and Andrew J. Dowdle
}

\begin{abstract}
Changes in campaign finance or other electoral laws often have unintended consequences. We demonstrate this effect by examining how the 2002 Bipartisan Campaign Reform Act helped alter the makeup of small, medium, and large dollar donors in the critical period known as the "invisible primary" before the Iowa Caucuses. The original concerns were that a few large dollar contributors would play a disproportionate role in funding bids and that candidates who had the ability to attract these large contributions would gain an unfair advantage. To measure the effects on contributor behavior, we examine candidate reports filed with the Federal Election Commission during the 2000-2016 presidential preprimaries. We find the impact and number of small contributions increased significantly following the passage of the 2002 legislation while the midsize and large contributions decreased. More importantly, this shift occurred well in advance of the Supreme Court's rulings prior to the 2012 contest. While this trend does have some positive aspects, we argue the decline of the midsize contributor will impact how nomination hopefuls fund their campaigns and eventually may undermine the political parties as entities themselves that are independent of the well-funded super PACs that have arisen in recent years.
\end{abstract}

Keywords: campaign finance reform, presidential nomination politics, invisible primary, American political behavior, Bipartisan Campaign Reform Act

$\mathbf{I}$ $\mathrm{N}$ RECENT YEARS, one of the most pressing concerns for campaign finance scholars has been to explain why the U.S. political system adopts policies that favor the preferences of the affluent over the middle- and working-class voters. ${ }^{1}$ The most prominent policies adopted by the United States have allowed the affluent to participate more effectively in the financing of electoral candidates, which raises concern about their ability to control the actions of elected officials. Whether campaign contributions actually "buy" votes or set the agenda on certain

Karen Sebold is a clinical assistant professor in the Department of Political Science at the University of Arkansas in Fayetteville, Arkansas. Andrew J. Dowdle is a professor in the Department of Political Science at the University of Arkansas in Fayetteville, Arkansas. issues is an intricate question. ${ }^{2}$ However, additional concerns arise about whether the disproportionate influence of the wealthy could also delegitimize the political process by discouraging popular participation,

\footnotetext{
${ }^{1}$ Kay Lehman Schlozman, "What Accent the Heavenly Chorus? Political Equality and the American Pressure System," 46(04) Journal of Politics (1984), p. 1006-1032; Larry M. Bartels, Unequal Democracy, Princeton University Press (2008); Martin Gilens, Affluence and Influence: Economic Inequality and Political Power in America, Princeton University Press (2012).

${ }^{2}$ Richard L. Hall and Frank W. Wayman, "Buying Time: Moneyed Interests and the Mobilization of Bias in Congressional Committees," 84(03) American Political Science Review (1990), p. 797-820; Michael Hadani and Douglas A. Schuler, "In Search of El Dorado: The Elusive Financial Returns on Corporate Political Investments," 34(2) Strategic Management Journal (2013), p. 165-181.
} 
or if their wealth may provide an unfair advantage to more prominent electoral candidates who have the ability to attract these large contributors. ${ }^{3}$

One of the places where these apprehensions are most evident is the presidential nomination process. In presidential nomination contests where fundraising success in the "invisible primary," or the year before the start of the Iowa Caucus, can "make or break" a candidate, large contributors might be even more important than in a congressional election. ${ }^{4}$ This creates a "money race" for early contributors as candidates vie for the muchneeded large contributions a strong campaign organization needs to propel themselves to victory well before the first vote has been cast. ${ }^{5}$ As the costs of campaigning rise, candidates need to raise their campaign money by reaching out to larger contributors. ${ }^{6}$ In the past, federal subsidies attempted to address this problem by encouraging candidates to raise more money from smaller contributors by offering a match on contributions less than $\$ 250$ per person. $^{7}$

Both the individual contribution limit of $\$ 1,000$ and the matching fund contribution threshold remained constant for almost three decades, until they were altered by the Bipartisan Campaign Reform Act of 2002 (BCRA), also commonly referred to as the McCain-Feingold Act. The McCainFeingold Act raised the legal limit for individual contributions above the previous $\$ 1,000$ legal ceiling while keeping the $\$ 250$ threshold for matching fund eligibility. ${ }^{8} \mathrm{~A}$ stagnation in the amount of matching public funds available, along with this increase in the amount individuals could contribute, disincentivized candidates from raising their campaign money from smaller contributors. These legal changes have likely altered how presidential candidates finance their campaigns and are leading to growing concern about the disproportionate role that a smaller number of high dollar contributors played in the fundraising process. ${ }^{9}$

Since the decision to contribute and the size of contributions are primarily individual-level phenomena, we assess individual-level contribution data to determine if these legal changes altered the behavior of individual contributors after 2002. To measure the potential impact of these changes on individual contributor behavior, we examine electoral candidate reports filed with the Federal Election Commission (FEC) during the 2000-2016 presidential preprimaries. We expect that the legal changes in the contribution limits are altering the behavior of individual contributors, both in absolute and relative terms. We also hypothesize that the consequences of these changes would likely substantiate the concerns of campaign finance scholars about the growing influence of large contributors and the concerns of presidential primary reform scholars about the increasing advantage well-known candidates have in attracting the large contributions. Next, we discuss the legal changes in contributor limits in more detail and then discuss the literature on presidential fundraising.

${ }^{3}$ David Damore, "Dynamic Modeling of Candidate Fundraising," 50(2) Political Research Quarterly (1997), p. 343-364; Peter Francia, Paul Herrnson, John C. Green, Lynda W. Powell, and Clyde Wilcox, The Financiers of Congressional Elections: Investors, Ideologues and Intimates, Columbia University (2003); Yvette M. Alex-Assensoh, Democracy at Risk: How Political Choices Undermine Citizen Participation and What We Can Do About It, Brookings Institute Press (2005); Michael J. Malbin, The Election After Reform: Money, Politics, and the Bipartisan Campaign Reform Act, Rowman \& Littlefield (2006a); Barbara Norrander, The Imperfect Primary: Oddities, Biases, and Strengths of U.S. Presidential Nomination Politics, Routledge Press (2010).

${ }^{4}$ Katherine Hinckley and John Green, "Fund-Raising in Presidential Nomination Campaigns: The Primary Lessons of 1988," 49(4) Political Research Quarterly (1996), p. 693718; Randall E. Adkins and Andrew. J. Dowdle, "The Money Primary: What Influences the Outcome of Preprimary Presidential Nomination Fundraising," 32 Presidential Studies Quarterly (2002), p. 256-275; William G. Mayer and Andrew Busch, The Front-Loading Problem in Presidential Nominations, Brookings Institute (2004).

${ }^{5}$ Frank Sorauf, Inside Campaign Finance: Myths and Realities, Yale University Press (1992); Clifford Brown, Lynda W. Powell, and Clyde Wilcox, Serious Money: Fundraising and Contributing in Presidential Nomination Campaigns, Cambridge University (1995); Adkins and Dowdle, supra note 4; Corwin Smidt and Dino Christenson, "More Bang for the Buck: Campaign Spending and Fundraising Success," 40(6) American Politics Research (2012), p. 949-975; Michael J. Goff, The Money Primary: The New Politics of the Early Presidential Nomination Process, Rowman \& Littlefield (2004).

${ }^{6}$ Brown, Powell, and Wilcox, supra note 5; Goff, supra note 5. ${ }^{7}$ Michael J. Malbin, "A Public Funding System in Jeopardy: Lessons from the Presidential Nomination Contest of 2004," 5(1) Election Law Journal (2006b), p. 2-22.

${ }^{8}$ Anthony Corrado, "Money and Politics: A History of Federal Campaign Finance Law," in Anthony Corrado, T. Mann, Daniel Ortiz, and Trevor Potter (eds.), The New Campaign Finance Sourcebook, Brookings Institute (2005).

${ }^{9}$ Nicholas Confessore, Sarah Cohen, and Karen Yourish, "Small Pool of Contributors Dominates Election Giving," New York Times (Aug. 2, 2015), <http://www.nytimes.com/2015/08/02/us/ small-pool-of-rich-contributors-dominates-election-giving.html>; Alex-Assensoh, supra note 3; Malbin, 2006b, supra note 7; Yasmin Dawood, "Campaign Finance and American Democracy," 18 Annual Review of Political Science (2015), p. 329-348. 


\section{CHANGES IN THE LEGAL REGULATIONS}

Given the importance of money in elections, the legal changes to the contribution limits should incentivize candidates to rely more on a smaller number of high dollar contributors. The 2010 Citizens United v. FEC ${ }^{10}$ decision by the Supreme Court that allows political action committees (PACs) to raise unlimited amounts of money, without disclosing their donors, receives most of the attention from the press because of the fear of the impact these "super PACs" will have on the political process. ${ }^{11}$ However, these fears do not appear to be playing out as proven by the failed candidacy of Jeb Bush in the Republican primary of 2016 or the failed candidacy of Hillary Clinton in the general election the same year. Bush had the most super PAC support during the nomination race, as these groups spent over $\$ 100$ million during his candidacy. The other legal changes that have received little attention from the media are the ones that removed the legal limits, or caps, from the contribution limits, and they may have a more significant effect on the process than the Citizens United decision. ${ }^{12}$

In 2002, Congress passed the McCain-Feingold Act, in an attempt to stem the growth in unregulated soft money. The Supreme Court's 1976 Buckley v. Valeo $^{13}$ decision, as well as other subsequent rulings in the 1980s and 1990s, created a series of loopholes that allowed unlimited and unregulated "soft money" raised by PACs and political parties to provide support to candidates in the form of electioneering communications for several election cycles in ways that evaded the limitations set down by the Federal Elections Campaign Act of 1971 and other subsequent post-Watergate campaign finance legislation. ${ }^{14}$ Congress finally passed the McCain-Feingold Act in 2002 to begin establishing regulations on this type of campaign spending and to make the process more transparent by limiting the number of days an electioneering communication can be made public prior to a primary election or general election. ${ }^{15}$

To offset the lack of soft money support that many candidates had come to rely on to subsidize their campaigns, especially congressional incumbents, McCain-Feingold raised the legal limit contributors can give to an electoral candidate in a two-year cycle. The FEC set the legal amount of $\$ 1,000$ per candidate, per election in 1971 as the maximum amount that can be contributed without creating the illusion of impropriety or quid pro quo. ${ }^{16}$ McCain-Feingold doubled the maximum to $\$ 2,000$ and indexed it for inflation in subsequent elections. ${ }^{17}$

However, Congress gave little thought to how these changes would influence the presidential nomination process, which had been dominated by federal matching funds and small dollar donors. The potential influence of larger contributors was then further exacerbated in 2014 by another significant change to the campaign finance legal environment when the U.S. Supreme Court stripped away the limitations on the aggregate limit contributors can make in a two-year election cycle in the McCutcheon v. FEC ${ }^{18}$ case. The majority opinion concluded that these restrictions were unconstitutional and that contributors had the right under the First Amendment to give to as many candidates in an electoral cycle as they would like, and therefore the aggregate limitation is unconstitutional. ${ }^{19}$

This decision to remove these limits furthers concerns about the influence of the wealthy in the political process. ${ }^{20}$ These changes to the legal contributor limit are likely to alter individual contributor behavior, incentivize candidates to raise their campaign money from fewer contributors, and might impact the fate of nomination hopefuls by giving the candidates with the most success in attracting high dollar donors an unfair electoral advantage especially given the dynamic of the fundraising process in the presidential elections.

The dynamics of presidential nomination politics have led candidates and their fundraisers to solicit the same donors time and time again. ${ }^{21}$ Presidential

\footnotetext{
${ }^{10} 558$ U.S. 310 (2010).

${ }^{11}$ Dawood, supra note 9.

${ }^{12}$ Michael Beckel, "The McCutcheon Decision ExplainedMore Money to Pour into the Political Process," Center for Public Integrity (Apr. 22, 2014), https://www.publicintegrity .org/2014/04/22/14611/mccutcheon-decision.

${ }^{13} 424$ U.S. 1 (1976).

${ }^{14}$ Corrado, supra note 8; Victoria Farrar-Myers and Diana Dwyre, Limits and Loopholes: The Quest for Money, Free Speech, and Fair Elections, CQ Press (2008).

${ }^{15}$ Corrado, supra note 8 .

${ }^{16}$ Id.

${ }^{17}$ Farrar-Myers and Dwyre, supra note 14.

${ }^{18} 134$ S. Ct. 1434 (2014).

${ }^{19}$ Beckel, supra note 12.

${ }^{20}$ Russell J. Dalton, Citizen Politics: Public Opinion and Political Parties in Advanced Industrial Democracies, Congressional Quarterly Press (2013).

${ }^{21}$ Brown, Powell, and Wilcox, supra note 5.
} 
candidates and their fundraising teams cultivated this "contributor pond" for cost effective reasons since it allows them to concentrate their outreach efforts and maximize their chance of fundraising success. By soliciting the same people repeatedly over numerous election cycles, presidential candidates and their fundraisers have established a "contributor pond" that candidates can dip their "fishing hooks" into every election.

The system of public finance that was created in the 1970s tried to broaden the pool of donors and encouraged the candidates to raise their funds from more contributors and in a greater number of states. ${ }^{22}$ The public finance formula provides a match of up to $\$ 250$ per donor in the primary to those candidates that choose to participate in the program. To qualify, candidates have to raise $\$ 5,000$ in $\$ 250$ increments in 20 or more states early in the primary. ${ }^{23}$ By the 2004 election, the FEC disbursements on the match to individual primary candidates reached $\$ 18.7$ million. ${ }^{24}$ In an environment where a successful nomination hopeful may need to spend $\$ 100$ million, these relatively low matching funds have led to several candidates in the recent past forgoing participation in the program.

At the same time, McCain-Feingold greatly increased the value of a large contribution while ignoring the now-outdated matching limits governing the public finance system, thus increasing the potential of candidates collecting their campaign funds from larger contributions, at the expense of the smaller contributions. Has ignoring the limits in the public finance system while increasing the legal contributor limit led to more candidates, who once would have relied on the public funds, to drop out of the system? This is an impossible question to answer, but we do know that far fewer presidential candidates have accepted matching funds after 2004 because the limits are too restrictive. While Steve Forbes's 1996 and George W. Bush's 2000 decisions predated the legal chances in the contribution limits, most serious hopefuls subsequently, with the notable exception of John McCain in 2008 who chose to participate in the system in the general election, chose not to accept public finance funds in their pursuit of their party's nomination.

Given this outdated public finance system and the increased need to raise money, it is likely candidates, who have finite time and money, are focusing their fundraising efforts in manners that will maximize their fundraising success by targeting a small number of wealthy contributors in the urban areas.
Even though the popular media highlighted President Barack Obama's success and Bernie Sanders's success in reaching small contributors, previous studies indicate that small contributors are typically one-time contributors who never contribute again. ${ }^{25}$ These contributors are drawn in by a specific candidate or issue and include thousands of individuals, but their voice has little chance to eclipse one "loud" individual whose interests and voice can be easily amplified by money, ${ }^{26}$ especially since the rise of well-funded super PACs in recent presidential contests.

\section{RESEARCH QUESTION AND METHODOLOGY}

To determine if there is a change in the behavior of individual contributors and to begin to understand how that might be affecting the competition, we address the following questions:

1. Has there been a shift toward large contributions after increasing the contributor limits?

2. If there has been a shift toward large contributions, which types of candidates are receiving the larger contributions?

We begin by measuring the distribution of contributions to presidential candidates in the preprimary period that occurred in the year before the Iowa Caucuses in the presidential primaries from 2000 to 2016. We assess the preprimary period in this study because fundraising during this period as discussed in the literature review is highly correlated with electoral success. We included the 2000 election because it is the only contest prior to McCainFeingold where the data is available in digital

\footnotetext{
${ }^{22} I d$; Malbin, 2006b, supra note 7.

${ }^{23}$ Malbin, 2006a, supra note 3.

${ }^{24}$ Corrado, supra note 8 .

${ }^{25}$ Stephen Ansolabehere, John M. de Figueiredo, and James M. Snyder Jr., "Why Is There So Little Money in U.S. Politics," 17(1) Journal of Economic Perspectives (2003) 105-130; Andrew J. Dowdle, Scott Limbocker, Song Yang, Karen Sebold, and Patrick Stewart, The Invisible Hands of Political Parties in Presidential Elections: Party Activists and Political Aggregation from 2004 to 2012, Palgrave Macmillan (2013). ${ }^{26}$ Diana Dwyre and Evelyn Braz, "Super PAC Spending Strategies and Goals," 13(2) The Forum (2015), p. 245-267; Richard L. Hasen, "Citizens United and the Illusion of Coherence," 109 Michigan Law Review (2011), p. 581-623.
} 
format, and it included nomination contests from each party. The elections of 2004, 2008, 2012, and 2016 happened after the McCain-Feingold Act and allow us evaluate the impact of the legal increase in the contribution limits.

We compiled a dataset that incorporated the FEC's records for contributions made to presidential candidates during these five election cycles, and these files yielded a total of more than 2.27 million contributions from more than 1.2 million contributors, totaling more than $\$ 1.4$ billion to 69 candidates running in the five election cycles. We then analyze the aggregate data by candidate and party to determine if there are changes in fundraising patterns after the legal increase in the contribution limits. We assess the data by total sum of contributions and by total count of contributions, observing the raw totals, and as a percentage of the total.

We also assess the contribution size and how each contribution size group contributes as a percentage of the overall total. We categorize contributions into three groups: (1) contributions at $\$ 200$ or less are coded as "small" contributions, (2) contributions that fall between $\$ 201-\$ 1,000$ (the maximum amount allowed before McCain-Feingold) are coded as "midsize" contributions, and (3) contributions between $\$ 1,001$ and the maximum amounts for an election cycle $(\$ 2,300$ in $2004, \$ 2,500$ in 2008 and 2012, and $\$ 2,700$ in 2016) are coded as "large" contributions. We also assess percentage change from cycle to cycle to determine if the legal increase in the contribution limits has altered the distribution of the contributions to presidential candidates in the preprimary. We include unitemized contributions, which contain no identifying information and are typically reported as one lump sum by campaigns to the FEC. Since federal law requires campaigns to only identify contributors giving more than $\$ 200$ in a given electoral cycle, we consider this as a separate category; however, they are still small contributions and are included when considering the percentage change from cycle to cycle.

To illustrate our findings, we create a boxplot using Excel, which reveals the inter-quartile ratio, or the measures of spread in the distribution of a set of numbers and in this case the count of contributions. The measures in the spread illustrated by this boxplot include the minimum, the maximum, the midpoint, and where the first and third quartiles in the distribution of the contributions lie. This is the best way to display visually the distribution of con- tributions before and after the increased contributor limit went into effect.

Lastly, we attempt to answer the second question about how shifting patterns of support among different types of contributors affects different types of presidential hopefuls. Table 1 lists each candidate included in the study and their respective classification. To create this typology, we slightly modify the Haynes et al. three-tier classification system by generating a three-tiered sorting of the candidates that utilizes the following criteria: (1) the number of elite endorsements, or endorsements given by a national officeholder or governor, during the preprima$\mathrm{ry}^{27}$ (elite endorsements are endorsements made by any current federal officeholder: representatives, senators, governors); (2) standing in the Gallup polls as a measure of public opinion support during the preprimary (Gallup poll standing is measured by each candidate's quarterly average of their weekly average in the Gallup polls); and (3) their duration in the race. ${ }^{28}$

With these factors in mind, the prominent candidates or the frontrunners that achieve a majority of the endorsements, or at least ten endorsements or more most quarters, and at least $20 \%$ or more in the polls consistently throughout the preprimary are labeled as a "Tier One" candidate. Competitive candidates who receive between three and nine endorsements most quarters and receive between $10 \%$ and $20 \%$ of support in the polls are labeled as a "Tier Two" candidate. Symbolic candidates, or the "also-rans," who receive few or no endorsements most quarters and receive $10 \%$ or less in the polls are labeled as a "Tier Three" candidate.

\section{FINDINGS}

Table 2 illustrates the total sum of contributions collected and reported by the presidential nomination candidates in the preprimary elections between 2000 and 2016. It also illustrates the total amount of money contributed in small, midsize, and large amounts and the percentage of the total for each of the categories of contributions for each election cycle.

\footnotetext{
${ }^{27}$ Audrey A. Haynes, Julianne F. Flowers, and Paul-Henri Gurian, "Getting the Message Out: Candidate Communication Strategy During the Invisible Primary," 55(3) Political Research Quarterly (2002), p. 633-652.

${ }^{28}$ We collected data from Real Clear Politics (2016), <http:// www.realclearpolitics.com/>.
} 
Table 1. Candidate Type

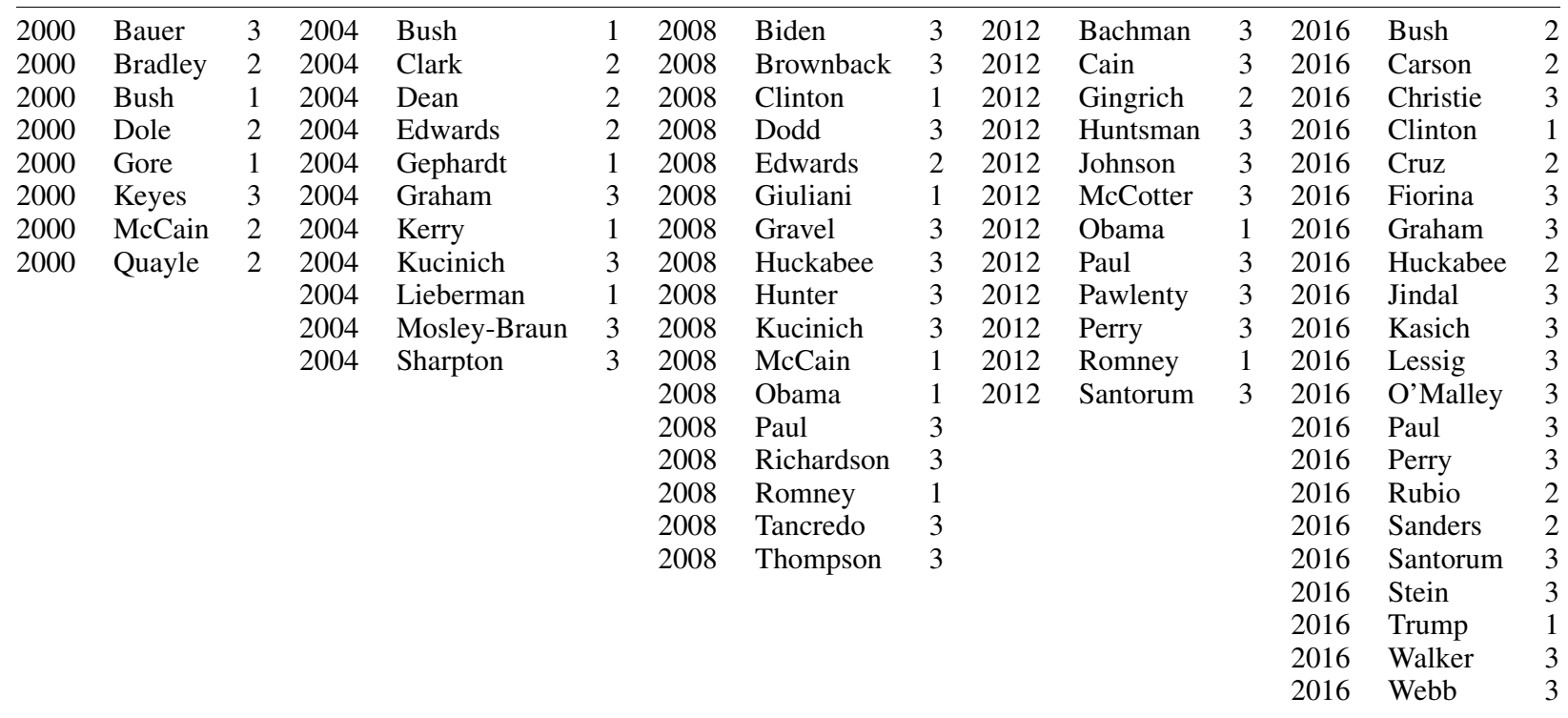

The total amount of money contributed during the preprimary grew significantly over this period from more than $\$ 180$ million in the 2000 cycle to over $\$ 335$ million in the 2016 cycle, with the notable exception of 2012. Large contributions are the greatest source of support during the 2004 and 2008 cycles, when it makes up $56 \%$ of the total money, but drop by the 2012 cycle to only $28 \%$ of the total financial support (in spite of the fact that the legal limit increases to $\$ 2,500$ ). The trend continues in 2016, which is surprising given there are contested nominations for both parties. Midsize contributions are the greatest source of support during the 2000 cycle, when they make up $84 \%$ of the total financial support to candidates, but wane to a low of $16 \%$ by the 2016 cycle. As we argue in the conclusion, this drop is problematic since this group would be more likely to serve as a check on the growing influence of larger donors. The most surprising aspect is the degree to which small contributions increased. Small contributions are the greatest source of support in the 2012 and 2016 cycles, as they make up over $47 \%$ and $58 \%$, respectively, in these cycles.

This monetary trend also represents a change in the raw number of individuals participating over the course of the last two electoral cycles. Table 3 illustrates the total count of contributions and the number of contributors collected and reported by the presidential nomination candidates in the

Table 2. Total Sum of Contributions to Presidential Nomination Candidates in the Preprimary Elections: 2000-2016

\begin{tabular}{|c|c|c|c|c|c|}
\hline Year & $\begin{array}{l}\text { Total contributions } \\
\quad(\text { millions \$) }\end{array}$ & $\begin{array}{l}\text { Unitemized contributions } \\
\text { (\% of total) }\end{array}$ & $\begin{array}{c}\text { Small itemized } \\
\text { contributions (\% of total) }\end{array}$ & $\begin{array}{c}\text { Mid-Range contributions } \\
\text { (\% of total) }\end{array}$ & $\begin{array}{c}\text { Large contributions } \\
\text { (\% of total) }\end{array}$ \\
\hline 2000 & $180,216,557$ & $\begin{array}{l}15,586,912 \\
(8.65)\end{array}$ & $\begin{array}{l}11,736,499 \\
(6.51)\end{array}$ & $\begin{array}{l}152,893,146 \\
(84.84)\end{array}$ & N/A \\
\hline 2004 & $229,311,579$ & $\begin{array}{l}23,552,132 \\
\quad(10.27)\end{array}$ & $\begin{array}{l}8,228,591 \\
(3.59)\end{array}$ & $\begin{array}{l}70,010,199 \\
(30.53)\end{array}$ & $\begin{array}{l}127,520,657 \\
\quad(55.61)\end{array}$ \\
\hline 2008 & $423,080,973$ & $\begin{array}{l}40,838,461 \\
(9.65)\end{array}$ & $\begin{array}{l}24,859,416 \\
\quad(5.88)\end{array}$ & $\begin{array}{l}116,511,392 \\
\quad(27.54)\end{array}$ & $\begin{array}{l}240,838,461 \\
\quad(56.93)\end{array}$ \\
\hline 2012 & $233,744,547$ & $\begin{array}{l}93,844,217 \\
(40.15)\end{array}$ & $\begin{array}{l}16,103,841 \\
(6.89)\end{array}$ & $\begin{array}{l}53,492,545 \\
(22.89)\end{array}$ & $\begin{array}{l}70,333,944 \\
(30.10)\end{array}$ \\
\hline 2016 & $335,490,123$ & $\begin{array}{l}157,883,691 \\
(47.06)\end{array}$ & $\begin{array}{l}30,547,701 \\
\quad(9.11)\end{array}$ & $\begin{array}{l}53,084,194 \\
(15.83)\end{array}$ & $\begin{array}{l}93,974,536 \\
(28.01)\end{array}$ \\
\hline
\end{tabular}

Note: The figure in parenthesis is the percentage of total money in that contest represented by that category of money. Small contributions are $\$ 200$ or less, mid-range contributions are $\$ 201-\$ 1,000$, large contributions are more than $\$ 1,000$. There are no large contributions reported for 2000 since contributions of more than $\$ 1,000$ were not allowed by federal law until 2002. 
Table 3. Total Count of Contributions to Presidential Nomination Candidates in the Preprimary Elections: 2000-2016

\begin{tabular}{|c|c|c|c|c|c|}
\hline Year & $\begin{array}{l}\text { Total contributors } \\
\text { (thousands \#) }\end{array}$ & $\begin{array}{l}\text { Total contributions } \\
\text { (thousands \#) }\end{array}$ & $\begin{array}{l}\text { Small contributions } \\
(\% \text { of total })\end{array}$ & $\begin{array}{c}\text { Mid-Range contributions } \\
\text { (\% of total) }\end{array}$ & $\begin{array}{c}\text { Large contributions } \\
(\% \text { of total })\end{array}$ \\
\hline 2000 & 102,000 & 273,077 & $\begin{array}{l}55,271 \\
(35.58)\end{array}$ & $\begin{array}{c}217,806 \\
(74.65)\end{array}$ & N/A \\
\hline 2004 & 197,000 & 395,587 & $\begin{array}{l}103,834 \\
(26.25)\end{array}$ & $\begin{array}{l}173,451 \\
(43.85)\end{array}$ & $\begin{array}{l}118,302 \\
(29.90)\end{array}$ \\
\hline 2008 & 503,000 & 958,459 & $\begin{array}{l}317,593 \\
(33.14)\end{array}$ & $\begin{array}{l}211,943 \\
(22.11)\end{array}$ & $\begin{array}{c}428,923 \\
(44.75)\end{array}$ \\
\hline 2012 & 187,000 & 378,592 & $\begin{array}{c}228,409 \\
(60.33)\end{array}$ & $\begin{array}{l}120,441 \\
(31.81)\end{array}$ & $\begin{array}{l}29,741 \\
(7.86)\end{array}$ \\
\hline 2016 & 259,945 & 713,606 & $\begin{array}{c}566,875 \\
(79.44)\end{array}$ & $\begin{array}{l}109,385 \\
(15.33)\end{array}$ & $\begin{array}{l}37,346 \\
(5.23)\end{array}$ \\
\hline
\end{tabular}

Note: The figure in parenthesis is the percentage of total money in that contest represented by that category of money. Small contributions are $\$ 200$ or less, mid-range contributions are $\$ 201-\$ 1,000$, large contributions are more than $\$ 1,000$. There are no large contributions reported for 2000 since contributions of more than $\$ 1,000$ were not allowed by federal law until 2002. The number of small contributors does not include unitemized contributions.

preprimary elections between 2000 and 2016. It does not include the unitemized contributions in the count of contributions or the number of contributors per contribution category, since they are not discernible.

A raw count of contributions also disproves the notion that large contributors are dominating the presidential campaign finance more in recent contests. Since 2008, the raw number of large and medium contributions has been dropping. The count of large contributions is the greatest in the 2008 cycle with a high of 439,000 contributions, a low of 29,000 in 2012 , and 37,000 in 2016 . The number of midsized contributions is the greatest in 2000 with a high of 218,000 , and a low of 109,000 in 2016. While the 2008 Republican and Democratic contests did generate a great deal of enthusiasm, the midsize and large-contributor support drop in 2012 and 2016, and is noticeable when compared to 2000 and 2004. The large contributions rose to a high of a high of nearly 429,000 in 2008 , but dropped significantly in 2016 to a high of more than 37,000 contributions in 2016. While contributors were limited to $\$ 1,000$ in 2000 , there were more than 217,000 contributors who contributed over $\$ 200$ as compared to only 109,000 such contributions in 2016, even though the total number of contributors increased from 102,000 in the 2000 cycle to over 259,945 contributors in the 2016 cycle. This is surprising and counters our expectations about the increase in the contribution limits.

In large part, this surge was because of the growing number of small contributors entering the system of presidential campaign finance in 2008 and 2016. Many credit the candidacies of Barack Obama and Bernie Sanders with drawing in new contributors giving small amounts of money. While the overall number of small contributors does not grow in 2016 the number of small contributions does, indicating many contributors may be giving multiple times. The total count of small contributions increased from over 55,000 in 2000 to more than 566,000 in 2016. These figures do not include the unitemized contributions. The increase in total unitemized dollars, however, suggests that if anything the number of small contributions has increased by even more than the figure we report in this article. These findings do not support our expectations about fundraising after the contribution limits increase. Next, we present the boxplots to better illustrate these findings.

Figure 1 utilizes boxplots to illustrate the impact the increasing number of small contributions is having on the distribution of contributions. The distribution for the 2000 and 2004 cycles is the most heavily shifted toward large contributions. By contrast, the proportion of small contributions in the election cycles rose dramatically after 2004, in spite of the increasing contribution limits that are indexed for inflation.

Figure 1 also shows partisan differences and provides insight into how the process has evolved across the last five presidential elections. In 2000, the Democratic candidates actually have a much higher median contribution than their Republicans rivals in the preprimary election, as their median 


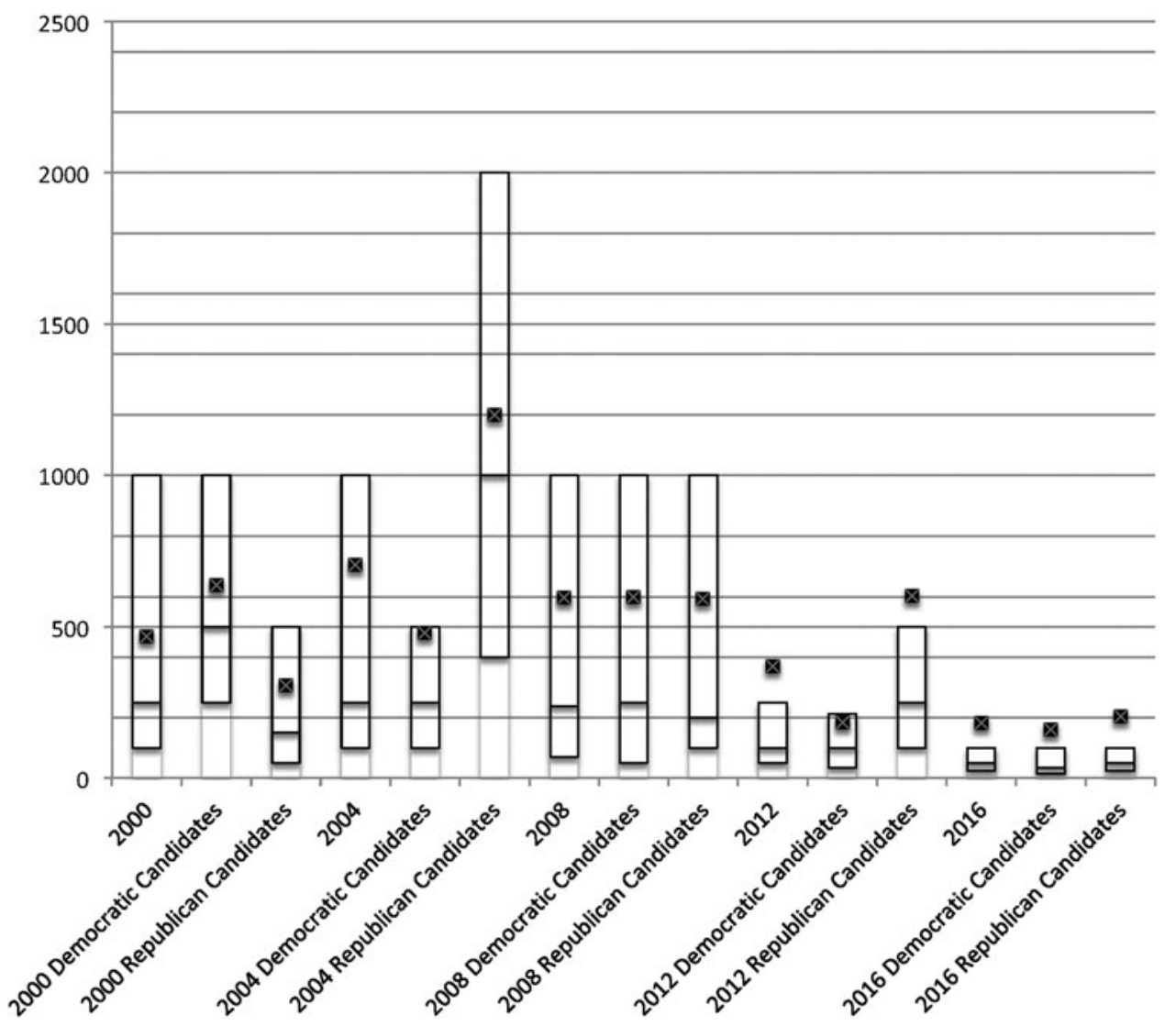

FIG. 1. Distribution of contributions by election: 2000-2016.

contribution amount is $\$ 500$ as compared to the Republican figure of $\$ 150$. The Democrats also have a higher first quartile at $\$ 250$, indicating fewer small contributions than Republican counterparts. In the 2004 cycle, there is a change in distribution after McCain-Feingold's legal increase to a $\$ 2,000$ maximum amount per contributor, and the Republican median contribution rises to $\$ 1,000$ and a quarter of Republican contributors give $\$ 2,000$. On the other hand, a large number of Democratic contributors in 2004 give $\$ 500$ or less. Much of this change was probably because the only Republican candidate was an incumbent president whose previous nomination campaign specialized in attracting large contributors. By contrast, the 2008 Republican and Democratic contenders have almost the same distributions for the invisible primary. Surprisingly, these distribution points were drastically lower than in the preceding elections.

In the many ways, these patterns serve as an auger for the 2012 and 2016 contests. In the 2012 cycle, the median contribution is $\$ 100$ with the
Democratic median contribution being at that level while the median Republicans is $\$ 250$. In 2016, the median contribution drops again to $\$ 50$ while the third quartile was a record-low $\$ 100$. The Democratic median contribution was $\$ 35$ while the Republican median figure was $\$ 50$. Both parties also have a third quartile of $\$ 100$. The midsize contributions continue to drop, causing the middle of the distribution to plummet, and given the significant increase in small contributor support, this is creating a bi-model distribution. However, it is unfair just to ascribe these new patterns to an army of small contributors mobilized by only the Democratic contenders President Barack Obama and Bernie Sanders. Republican candidates like Ron Paul and Donald Trump in 2016, and various Republican contenders in 2012, are also raising record low numbers of large contributions in spite of the increasing legal contribution limits.

While our article has focused on the decision to contribute and the size of contributions primarily as individual-level phenomena, these actions do 
have effect beyond just an expressive act of political behavior. We briefly touch on the implications that these changing patterns have on both presidential aspirants and the parties themselves. It is important to understand that not all types of candidates are affected in a uniform manner by these changes in contributor behavior. In Table 4, we assess which party and which candidates are benefiting from the different types of financial support.

The finding here poses the results we discussed from Figure 1 in a somewhat different light. Republican candidates actually rely more on both small and large money contributions than their Democratic rivals. Only $17.55 \%$ of their preprimary support on average comes from individuals who contribute between $\$ 201$ and $\$ 1,000$, as opposed to nearly onethird of the Democratic rivals whose contributions are primarily from this category. At the same time, Republicans are more reliant on large contributions and receive over $46 \%$ of their funding from this category in contrast to the $37 \%$ of funding for Democratic aspirants.

Utilizing the typology described in the methodology section, it becomes evident that not only does partisanship affect fundraising but candidate status does as well. As Table 5 shows, Tier One candidates receive more of their support from large contributions while Tier Two aspirants tend to get more of their relative backing from small contributions. Tier Three hopefuls, by contrast, garner equivalent levels of money from each of the three classes of contributions. Table 5 indicates that while McCain-Feingold's increase in the $\$ 1,000$ hard money contribution limit benefitted Tier One candidates regardless of party, GOP frontrunners benefit more than their counterparts. While only $46 \%$ of Democratic Tier One candidate money comes from large contributors, large contributors account for nearly $61 \%$ of Republican Tier One candidate money.

Table 4. Small Contribution Versus Large Contribution Support by Party, 2004-2016

\begin{tabular}{lccc}
\hline $\begin{array}{l}\text { Party } \\
\text { of candidate }\end{array}$ & $\begin{array}{c}\text { Small } \\
\text { contributions }\end{array}$ & $\begin{array}{c}\text { Medium } \\
\text { contributions }\end{array}$ & $\begin{array}{c}\text { Large } \\
\text { contributions }\end{array}$ \\
\hline Republican & $36.08 \%$ & $17.55 \%$ & $46.37 \%$ \\
Democratic & $30.15 \%$ & $32.92 \%$ & $36.93 \%$ \\
\hline
\end{tabular}

Note: The figures in each cell represent the percentage of total contributions from a specific type of contributor. Small contributions are \$200 or less, mid-range contributions are $\$ 201-\$ 1,000$, large contributions are more than $\$ 1,000$.
Table 5. Small Contribution Versus Large Contribution Support by Candidate Tiers, 2004-2016

\begin{tabular}{lccc}
\hline $\begin{array}{l}\text { Tier of } \\
\text { candidate }\end{array}$ & $\begin{array}{c}\text { Small } \\
\text { contributions }\end{array}$ & $\begin{array}{c}\text { Medium } \\
\text { contributions }\end{array}$ & $\begin{array}{c}\text { Large } \\
\text { contributions }\end{array}$ \\
\hline Tier One & $18.76 \%$ & $29.24 \%$ & $52.95 \%$ \\
Tier Two & $54.51 \%$ & $11.46 \%$ & $34.03 \%$ \\
Tier Three & $34.91 \%$ & $25.97 \%$ & $39.12 \%$ \\
\hline
\end{tabular}

Note: The figures in each cell represent the percentage of total contributions from a specific type of contribution. Small contributions are $\$ 200$ or less, mid-range contributions are $\$ 201-\$ 1,000$, large contributions are more than $\$ 1,000$.

\section{DISCUSSION OF FINDINGS}

In comparison to the 2004 and 2008 preprimaries, we find that that the impact and number of large contributions actually decreases in 2012 and only rebounds to 2004 levels in 2016 in absolute, but not in relative terms. Midsize contributions actually decrease in absolute and relative importance in financing presidential campaigns. Surprisingly, the relative and absolute number of small contributions increases during this period, which has been largely attributed to President Obama and Bernie Sanders, but several GOP candidates are also receiving a large number of small contributions as well. These findings indicate that the composition of contributions is changing but not necessarily in the direction that was expected.

These patterns were not uniform across candidates, however, as high-profile contenders such as President George W. Bush, Mitt Romney, and Hillary Clinton relied more on large contributions. Still, this reliance comes at a price if front-runners are not able to win over small contribution support as well. In 2008, Hillary Clinton's large elite contributor network was not enough to give her the upper hand in the Democratic nomination contest with President Barack Obama, who attracted many new contributors, especially small contributors. He continued this pattern in 2012. Unlike President George W. Bush, who relied on large contributions in the preprimary to launch his initial 2000 nomination bid and finance the early days of his 2004 reelection bid, President Barack Obama may have been the most balanced fundraiser in recent history. He managed to raise large sums from small, medium, and large contributors. The effort from tens of thousands of small contributors, who gave at a time when most people were not paying attention to either the primaries or the upcoming general election, was especially 
remarkable. This was a similar story for Bernie Sanders and Donald Trump in the 2016 preprimary.

This example suggests that overreliance on large contributions during the early stage of the primary race may have negative implications beyond the primary season. In contrast to President Barack Obama, Hillary Clinton's 2016 campaign, which continued to rely on large contributions, still struggled to mobilize support from small contributors two months before the general election as opposed to her opponent Donald Trump. ${ }^{29}$ Similarly, nominees such as John Kerry in 2004 and Mitt Romney in 2012 survived a relatively poor record of wooing small contributors in the preprimary season, only to lose in the general election. Furthermore, in the 2016 election, candidates such as Jeb Bush with a strong large contributor network did not fare as well compared to candidates who were much less successful at raising serious money, such as Donald Trump, John Kasich, or Marco Rubio. While it is too soon to tell if this link is a casual one or simply a correlation, it seems evident that success with small contributors seems to bode well for potential nominees.

This article leaves many unanswered questions for future studies. Why has the number of small contributions increased so dramatically? Is the increase driven by technological, generational, or political polarization, or other general social changes within the United States? And while these types of contributions have surged, why have large contributions grown stagnate and midsize contributions declined during the preprimary period? Are these contributors simply following the cues of elites, who still endorse candidates but are more likely to wait until after the preprimary has finished and the formal contests have begun? ${ }^{30}$

A reflexive response would be that they contributed to the super PACs, which exist without the contribution limits regulating contributions directly to candidates. The problem is that there are not enough contributors to these organizations to account for the overall decrease. And if these contributors are not "migrating" to these groups, are they scaling back their contributions or foregoing them all together because of these former mid- and large-sized contributors who believe a $\$ 500$ or $\$ 1,000$ contribution does not matter as much as it once did? And if these activists are exiting, what does the rise of small contributors mean in a political system where the "active public" has traditionally been small? ${ }^{31}$ These findings are surprising and lead to more questions, which we address next in the conclusion.

\section{CONCLUSION}

In one sense, this rise of small contributions would seem to be a welcome occurrence. Since the 2000 presidential election, observers have worried about the diminishing importance of small contributors in a presidential nomination financing process that once relied on their contributions and the federal subsidies that their contributions triggered. ${ }^{32}$ Considering the important role of small contributors, not only as sources of money, but as activists mobilizing other voters in the general elections, the rising number of small contributors would be a positive phenomenon for parties in a cadre-based system. Advocates of small contributors might also see this trend as a reversal of Michels' iron law of oligarchy, at least at the financial level. $^{33}$

On the other hand, there is a danger in ignoring the absolute and relative decline of midsized contributions. In fact, one can argue that these contributors actually represent a declining middle class of party contributors and the candidates they support. As such in a cadre system of parties, this revelation is likely to be important in regards to mobilizing support on Election Day. While smaller contributors may fill that vacuum, there is much that we do not know about them. Is a small commitment of $\$ 20$ or $\$ 50$ as likely to spur a commitment towards party activism on Election Day? More importantly in terms of party-building, are they as likely to remain active from election to election or are they

\footnotetext{
${ }^{29}$ Jonathan Martin, "Liberals See Hillary Clinton's Focus on Big Donors as Bafflingly Dated,” New York Times (Sept. 21, 2016). Nicholas Confessore and Nick Corasaniti, "Fueled by Small Contributions, Donald Trump Makes Up Major Financial Ground," New York Times (Aug. 4, 2016), <http://www.nytimes.com/ 2016/08/04/us/politics/trump-fundraising.html?>.

${ }^{30}$ Wayne P. Steger, A Citizen's Guide to Presidential Nominations: The Competition for Leadership, Routledge Press (2015).

${ }^{31}$ Angus Campbell, Philip E. Converse, Warren E. Miller, and Donald E. Stokes, The American Voter, John Wiley and Sons (1960).

${ }^{32}$ Malbin, 2006b, supra note 7; Brendan Doherty, The Rise of the President's Permanent Campaign, University of Kansas Press (2012).

${ }^{33}$ Robert Michels, Political Parties, Hearst's International Library Company (1915).
} 
more characteristic of the one-time contributor described by Ansolabehere, De Figueiredo, and Snyder, as opposed to the middle dollar donors who played a much larger role and habitual prior to $2002 ?^{34}$ While small dollar contributors are attracted by a specific candidate or issue, does their voice have the ability to eclipse one "loud" individual who speaks through a well-funded super PAC, in contrast to the $\$ 500$ or $\$ 1,000$ donors who dominated campaign finance for most of the post-Watergate period?

In an election cycle where campaigns routinely spend tens of millions of dollars, it is unlikely that any one large direct contributor, or even a "bundler" of dozens of direct large contributions, has the effect of the well-funded super PAC. These contributors, such as Sheldon Adelson and the Koch Brothers on the Republican side, or George Soros and Tom Steyer on the Democratic side, have the ability to buy a very loud "megaphone" to amplify their political voices. These sources of money are relatively new in the world of presidential campaign finance, and they are quickly becoming major players in funding both presidential nomination and general election bids. In many ways, it can be argued that their entrance in the arena of presidential campaign finance has already begun to erode the system we describe in this article. While the scope of their activities are beyond of the scope of this study, it is important to remember that these contributors now are beginning to form part of long-time active networks within parties and not likely to disappear anytime soon.

\section{REFERENCES}

Adkins, Randall E., and Andrew. J. Dowdle. 2002. "The Money Primary: What Influences the Outcome of Preprimary Presidential Nomination Fundraising?" Presidential Studies Quarterly 32: 256-275.

Alex-Assensoh, Yvette M. 2005. Democracy at Risk: How Political Choices Undermine Citizen Participation and What We Can Do About It. Washington DC: Brookings Institute Press.

Ansolabehere, S., de Figueiredo, J.M., and Snyder, J.M. 2003. "Why Is There So Little Money in U.S. Politics?" Journal of Economic Perspectives 17(1): 105-130.

Bartels, Larry M. 2016. Unequal Democracy. Princeton, NJ: Princeton University Press.

Beckel, Michael. 2014. "The McCutcheon Decision ExplainedMore Money to Pour into the Political Process." Center for Public Integrity. Apr. 22. <https://www.publicintegrity.org/ 2014/04/22/14611/mccutcheon-decision-explained-more- money-pour-political-process $>$ (accessed on Sept. 19, 2016).

Brown, Clifford, Lynda W. Powell, and Clyde Wilcox. 1995. Serious Money: Fundraising and Contributing in Presidential Nomination Campaigns. Cambridge: Cambridge University.

Buckley v. Valeo, 424 U.S. 1 (1976).

Campbell, Angus, Philip E. Converse, Warren E. Miller, and Donald E. Stokes. 1960. The American Voter. New York: John Wiley and Sons.

Citizens United v. FEC, 558 U.S. 310 (2010).

Confessore, Nicholas, Sarah Cohen, and Karen Yourish. 2015. "Small Pool of Contributors Dominates Election Giving." New York Times. Aug. 2. <http://www.nytimes.com/2015/08/ 02/us/small-pool-of-rich-contributors-dominates-electiongiving.html > (accessed on Aug. 11, 2016).

Confessore, Nicholas, and Nick Corasaniti. 2016. "Fueled by Small Contributions, Donald Trump Makes Up Major Financial Ground.” New York Times. Aug. 4. <http://www .nytimes.com/2016/08/04/us/politics/trump-fundraising.html?> (accessed on Sept. 22, 2016).

Corrado, Anthony. 2005. Chapter One, "Money and Politics: A History of Federal Campaign Finance Law." In The New Campaign Finance Sourcebook. Anthony Corrado, T. Mann, Daniel Ortiz, and Trevor Potter (eds.). Washington, DC: Brookings Institute.

Dalton, Russell J. 2013. Citizen Politics: Public Opinion and Political Parties in Advanced Industrial Democracies. Washington, DC: Congressional Quarterly Press.

Damore, David. 1997. "Dynamic Modeling of Candidate Fundraising." Political Research Quarterly 50(2): 343-364.

Dawood, Yasmin. 2015. "Campaign Finance and American Democracy." Annual Review of Political Science (18): 329-348.

Doherty, Brendan. 2012. The Rise of the President's Permanent Campaign. Lawrence, KS: University of Kansas Press.

Dowdle, Andrew, Scott Limbocker, Song Yang, Karen Sebold, and Patrick Stewart. 2013. The Invisible Hands of Political Parties in Presidential Elections: Party Activists and Political Aggregation from 2004 to 2012. London: Palgrave Macmillan.

Dwyre, Diana, and Evelyn Braz. 2015. "Super PAC Spending Strategies and Goals." The Forum 13(2): 245-267.

Farrar-Myers, Victoria, and Diana Dwyre. 2008. Limits and Loopholes: The Quest for Money, Free Speech, and Fair Elections. Washington, DC: CQ Press.

Francia, Peter, Paul Herrnson, John C. Green, Lynda W. Powell, and Clyde Wilcox, 2003. The Financiers of Congressional Elections: Investors, Ideologues and Intimates. New York: Columbia University.

Gilens, Martin. 2012. Affluence and Influence: Economic Inequality and Political Power in America. Princeton, NJ: Princeton University Press.

Goff, Michael J. 2004. The Money Primary: The New Politics of the Early Presidential Nomination Process. Lanham, MD: Rowman \& Littlefield.

${ }^{34}$ Ansolabehere, de Figueiredo, and Snyder, supra note 25. 
Hadani, Michael, and Douglas A. Schuler. 2013. "In Search of El Dorado: The Elusive Financial Returns on Corporate Political Investments.” Strategic Management Journal 34(2): 165-181.

Hall, Richard L., and Frank W. Wayman. 1990. "Buying Time: Moneyed Interests and the Mobilization of Bias in Congressional Committees." American Political Science Review 84(03): 797-820.

Hasen, Richard L. 2011. "Citizens United and the Illusion of Coherence." Michigan Law Review 109: 581-623.

Haynes, Audrey A., Julianne F. Flowers, and Paul-Henri Gurian. 2002. "Getting the Message Out: Candidate Communication Strategy During the Invisible Primary." Political Research Quarterly 55(3): 633-652.

Hinckley, Katherine, and John Green. 1996. "Fund-Raising in Presidential Nomination Campaigns: The Primary Lessons of 1988." Political Research Quarterly 49(4): 693-718.

Malbin, Michael J. 2006a. The Election After Reform: Money, Politics, and the Bipartisan Campaign Reform Act. Washington, DC: Rowman \& Littlefield.

Malbin, Michael J. 2006b. "A Public Funding System in Jeopardy: Lessons from the Presidential Nomination Contest of 2004." Election Law Journal 5(1): 2-22.

Martin, Jonathan. 2016. "Liberals See Hillary Clinton's Focus on Big Donors as Bafflingly Dated." New York Times.com. Sep. 21. <https://www.nytimes.com/2016/09/22/us/politics/ hillary-clinton-money-obama.html> (accessed on Sep. 2, 2018).
Mayer, William G., and Andrew Busch. 2004. The FrontLoading Problem in Presidential Nominations. Washington, DC: Brookings Institute.

McCutcheon v. FEC, 134 S. Ct. 1434 (2014).

Michels, Robert. 1915. Political Parties. New York: Hearst's International Library Co.

Norrander, Barbara. 2010. The Imperfect Primary: Oddities, Biases, and Strengths of U.S. Presidential Nomination Politics. New York: Routledge.

Schlozman, Kay Lehman. 1984. "What Accent the Heavenly Chorus? Political Equality and the American Pressure System." Journal of Politics 46(04): 1006-1032.

Sorauf, Frank. 1992. Inside Campaign Finance: Myths and Realities. New Haven, CT: Yale University Press.

Smidt, Corwin, and Dino Christenson. 2012. "More Bang for the Buck: Campaign Spending and Fundraising Success." American Politics Research 40(6): 949-975.

Steger, Wayne P. 2015. A Citizen's Guide to Presidential Nominations: The Competition for Leadership. New York: Routledge.

Address correspondence to: Karen Sebold

Department of Political Science University of Arkansas 428 Old Main Fayetteville, AR 72730

E-mail: ksebold@uark.edu 